\title{
AZ AGRESSZIÓ MEGNYILVÁNULÁSA A KREATIVITÁSTESZTEKBEN
}

\author{
Szerzők: \\ Mező Katalin (PhD.) \\ Debreceni Egyetem (Magyarország) \\ Mezô Ferenc (PhD.) \\ Eszterházy Károly Katolikus Egyetem \\ (Magyarország) \\ Első szerző e-mail címe: \\ kata.mezo1@gmail.com
}

\author{
Lektorok: \\ Hanák Zsuzsanna (PhD.) \\ Eszterházy Károly Katolikus Egyetem \\ (Magyarország) \\ Kelemen Lajos (PhD.) \\ Poliforma Kft. (Magyarország)
}

...és további két anonim lektor

Mező Katalin, Mező Ferenc (2021). Az agresszió megnyilvánulása a kreativitástesztekben. Különleges Bánásmód, 7. (3). 43-55. DOI 10.18458/KB.2021.3.43

\begin{abstract}
Abszrakt
Noha az agresszió és a kreativitás kölcsönhatása már az 1900-as évek kezdetétól kutatott terület, annak lehetősége, hogy a kreativitástesztek az agresszió vizsgálatára is alkalmasak lehetnek mégis újszerű. Jelen tanulmányban (egy agresszió-mutató kidolgozását és validálását célzó hosszabb távú kutatás elővizsgálataként) a kreativitástesztekben megjelenő agresszív válaszok gyakoriságára, korrelációira fókuszálunk. Módszer: a Szokatlan használat és a Körök teszt (verbális és nem verbális kreativitástesztek) ingereire adott agresszív válaszok számának különbségeit, korrelációs kapcsolatait elemezzük (N=356 fő). Eredményeink szerint a kreativitástesztek különböző ingereire adott agresszív válaszok száma: a) szignifikánsan különböző ( $p<0,001)$; b) nem korrelál jól egymással (max $r=0,414)$; c) függ $(p<0,001)$ a nem és a kor alapján képzett mintaváltozóktól. A kreativitástesztek esetében lehetségesnek tartjuk egy speciális agressziómutató kidolgozását, de e munka során figyelembe kell vennünk jelen tanulmány eredményeit.
\end{abstract}

Kulcsszavak: kreativitás, agresszió, kreativitástesztek

Diszciplína: pszichológia

\section{Abstract}

MANIFESTATION OF AGGRESSION IN THE CREATIVITY TESTS

Although the research of interaction of aggression and creativity dates back to the beginning of the early 1900 , the possibility of creativity tests to use to examine aggression is novel. In the present study (as a prestudy of long-term research which aimed to create and validate an aggression index) we focus on 
frequency and correlations of aggressive responses which manifest in creativity tests. Methods. We analyze the differences and correlations of a number of aggressive responses which were given to stimuli the Unusual Uses and the Circle test (verbal and nonverbal creativity tests; $\mathrm{N}=356$ people). According to our results, the numbers of aggressive responses to the different stimuli of creativity tests: a) are significantly different $(p<0,001), b)$ do not correlate with each other widely ( $\max r=0,414)$, $c$ ) depend on samplevariables of gender and age. In the case of creativity tests, we think it is possible to elaborate on a special aggression index, but during this work, we have to consider the results of this study.

Keywords: creativity, aggression, creativity test

Dicipline: psychology

Annak ellenére, hogy a kreativitást többnyire szükséges, konstruktív és kiemelkedően fontos képességként jellemzik, napjainkban megjelentek azok a kutatások is, melyek a kreativitás negatívabb, sötét oldalát vizsgálják (Cropley, Kaufman és Cropley, 2008; Cropley, Kaufman, White és Chiera, 2014; Prechtold-Stefan és mtsai, 2020). A jelenség leírására egyre gyakrabban a rosszindulatú kreativitás (malevolent creativity, MC) illetve a negatív kreativitás (negative creativity, NC) fogalmat használják. A rosszindulatú kreativitás, a kreatív gondolkodási képesség rosszindulatú, erőszakos vagy romboló célok elérésére való hasznosítását jelenti (Runco, 2010; Cropley és mtsai, 2014), a negatív kreativitás viszont, arra utal, amikor a kreativitás a rosszindulatú szándékok nélkül káros másokra (James és mtsai, 1999).

Az agresszió és a kreativitás kapcsolata két irányból is megközelíthető. Egyfelől az agresszivitás kreativitást facilitáló hatása felól - lásd például: Landau (1994) „az agresszivitás kreativitást szül” megállapítását, vagy gondoljunk a kreativitást a tudatalatti konfliktusokból származtató pszichoanalitikus megközelítésre, melyben a kreatív teljesítmény a szublimált agresszió eredménye (vö.: Kőváry, 2012), illetve Berkowitz (1990) kognitív neoasszociációs elméletére. Másfelől a kreativitás gyakran említett korrelátumai a pszichoticizmussal, agresszív megnyilvánulásokkal, s az originalitásból eredő (a megfigyelők által akár agresszívnek is címkézhető) devianciával függnek össze (vö: Gyarmathy, 2011; Jonason és mtsai).

Jelen tanulmány (mint egy több lépésből álló vizsgálatsorozat elsô, helyzetfeltáró elôvizsgálati elemének) célja: a kreativitástesztekben megnyilvánuló agresszió kvantitatív elemzése egy hosszabb távú (agresszió-mutató kidolgozását és validálását célzó) kutatás érdekében. A kognitív tesztek vizsgálati változóin túlmutató diagnosztikai lehetôségek gondolata önmagában nem új keletű (intelligenciatesztekkel kapcsolatban például lásd: Szakács, 1987); s fordítva: az elsősorban nem kognitív vonások vizsgálatára kidolgozott eljárások (például Rorschrach próba, Fateszt, Metamorfózis teszt) esetében szintén találunk példát kreativitás változókra (fluenciára, originalitásra, flexibilitásra) is fókuszáló eljárásokra. Azonban figyelemfelkeltő, hogy a teljesítménytesztekben megjelenő rosszindulatú kreativitás és a hagyományos kreatív ötletek közötti összefüggés feltárására nem helyeződött kellő hangsúly a korábbiakban, holott már Jonason és mtsai (2017) is arra a megállapításra jutottak, hogy pozitív korreláció van a szokatlan használat feladatban generált ötletek esetében a negatív kreativitás és az egyéb változók között. Emellett Dumas és Sricland (2018) is arról számolt be, hogy a szokatlan használat feladatban az ötletek eredetisége és az ötletek kéretlen rosszindulatúsága között 
pozitív korreláció van. Megközelítésünk újszerûségét az adja, hogy a hazánkban leggyakrabban használt kreativitástesztekkel kapcsolatban vetjük fel egy jóformán „tesztidegen” személyiségváltozó vizsgálati lehetőségét.

A továbbiakban áttekintjük a kreativitás és az agresszió kapcsolatának pszichológiai megközelítéseit, vizsgálati lehetôségeiket, majd közöljük a kreativitástesztekben megnyilvánuló agresszivitásra vonatkozó elővizsgálati eredményeinket.

\section{A kreativitás és az agresszió kapcsolatának pszichológiai megközelítései}

A kreativitás és agresszió kapcsolatának pszichoanalitikus orientációjú megközelítéseit tekintve mindenekelőtt kell megemlítenünk, hogy 1917-ben Freud (1986) az alkotó folyamat dinamikája mögött három tényező interakcióját vetette fel - ezek: a) felfokozott fantáziatevékenység (melyet legtöbbször erotikus vágy indukál); b) szublimáció (a fantáziaképződmények kreatív átalakítása távolítás, mérséklés, formába öntés révén); c) a vágyak áttételes kielégítése (mely örömöt okoz alkotónak, múélvezőnek egyaránt). Heinz Hartmann (1955) felvetette, hogy a szexuális ösztönkésztetés mellett az agresszív drive is szublimálódhat, s a neutralizáció fogalom bevezetését javasolta a szexuális és agresszív ösztönenergiák semlegesítésére történő utaláskor. Más megközelítésben a tárgykapcsolatelméletek (pl. Klein, 1999; Winnicott, 1999) a kreativitást már nem feltétlenül pszichopatológiai eredetû lelki múködés eredményeként értelmezik, hanem az egészséges személyiség velejárójaként is említik (Mentzos, 2003). Melanie Klein (1999) a kreativitást a korai énfejlődéssel, s azon belül a csecsemő saját romboló késztetéseiből táplálkozó depresszív pozícióval hozza összefüggésbe, amelyre szimbolizációval, kreativitással, szublimációval járó „helyreállítással” reagálhat - hacsak nem mániás elhárítás/helyreállítás követi azt. Winnicott (1999) az első életévben kialakuló potenciális tér tárgyaival köti össze a csecsemő primer kreativitását, ami a későbbi kreatív folyamatok alapja is egyben.

A neoanalitikus (pszichoszociális) orientációjú elméletalkotók (Sullivan, 1996; Fromm, 1959; Erikson, 2002) a kreativitást az egyén és a szociális környezetének konfliktusos kölcsönhatásával magyarázzák. Az individuálpszichológiai nézőpont a kreativitás kompenzációs teóriáját veti fel: a vélt vagy való fogyatékosságaink kompenzálásának eredménye vezethet kisebb-nagyobb kreatív teljesítményekhez (Adler, 1991).

A humanisztikus pszichológusok (pl. Rogers, 2004; Maslow, 2003; May, 2009) a kreativitást az emberi lét autentikus kifejeződésének tartják (ami akár agresszív viselkedésben is manifesztálódhat).

A gestalt-pszichológiai megközelítés aspektusából Koestler (1998) alkotáselméletében a kreativitás két lehetséges módja: az álomszerú állapotba merülés, illetve a biszociáció (két síkon történő egyidejü gondolkodás). Ezekhez az energiát pedig affektív tényezők (pl. szerelem és agresszió) szolgáltatják.

A tradicionális behaviorista megközelítés ingerválasz (S-R) sémája szerint a kreativitás és az agresszió egyaránt válasz az azt előidéző környezeti ingerekre, s ha e válaszreakciókat pozitív megerősítés kíséri (legalábbis nem követi negatív megerősítés), akkor a jövőbeli előfordulási gyakoriságuk megnő.

A kognitív megközelítés egyrészt az asszociációs elméletre - vö.: Mednick (1962) távoli asszociációs elmélete -, másrészt a kognitív rendszerek átviteli elméletére (Guilford, 1959) épül. A kognitív szemléletű kutatások egy vonulata az agresszió és a kreativitás korrelációit és oksági összefüggéseit célozza, s a kreativitást előidéző, illetve az azzal járó destruktivitásra fókuszál (Cropley és tsai., 2010; Dacey és Lennon, 1998). Tacher és Readdick (2006) például kimutatta az agresszió és a kreativitás korrelációját a verbális területen. Eredményeik szerint a TTCT verbális fluencia, flexibilitás és originalitás értékei korreláltak $(r>0,42)$ a verbális agresszió megfigyelhetô, illetve tanárok 
által jelzett értékeivel. A verbális kreativitás a fizikai agresszióval és az azzal való fenyegetéssel is korrelált. Runco és Sakamoto (1999) szerint a kreatív gyerekek impulzívabbak, érzékenyebbek lehetnek a környezeti ingerekre és arousal szintjük is változékonyabb. A felnőtteket tekintve Feist (1999) azt találta, hogy a kreatív kutatók és múvészek arrogánsabbak, ellenségesebbek és nagyobb hatalomvágyat mutatnak másoknál.

\section{A kreativitás vizsgálati lehetőségei}

A kreativitást vizsgáló pszichológiai eljárások elsősorban az önjellemzó kérdőívek, illetve a tesztek csoportjába sorolhatók. A kérdőíves eljárások közé sorolhatók például: Tóth-féle Kreativitást Becslő Skála (TKBS - Tóth, 2011; Tóth és Király, 2006); Creativity Checklist (Johnson, 1979); Group Inventory for Finding Creative Talent (GIFT Rimm és Culbertson, 1980); Group Inventory for Finding Interests (GIFF I., II. - Davis és Rimm, 1982); Creative Behavior Inventory (Kirschenbaum, 1989); Creativity Styles Questionnaire (CSQ Kumar, Kemmler és Holman, 1997). A kreativitás projektív tesztekkel is vizsgálható. Az agresszió vizsgálatára alkalmas Rorschach-próbában (vö.: Mérei, 2002) lehetőség van például a Torrance-féle tesztekben is használt fluencia (ötletgazdagság), originalitás (eredeti gondolkodás) és flexibilitás (rugalmas gondolkodás) változók vizsgálatára is.

A fluencia megítélésére - a Torrance-féle tesztekhez hasonlóan - ebben a tesztben is a kreatívnak értékelhető válaszok száma ad lehetôséget. Az ori-ginalitást a teljesítménytesztekhez hasonló válasz-ritkaság alapján becsülhetjük meg (lásd: „Orig.” válaszok száma a Rorschach jegyzókönyv negyedik oszlopában). A flexibilitást pedig a Rorschach jegyzőkönyv harmadik oszlopában jelölt „tartalmi körök” számával hozhatjuk párhuzamba. Ehhez hasonló a Fa-rajz teszt (vö.: Süle, 1988) és a Me-tamorfózisok teszt (vö.: Szőnyi, 1988) kreativitást pontozó szisztémája is.
A teljesítménytesztek tekintetében a Magyarországon leggyakrabban használt kreativitástesztek leírása a Zétényi Tamás (1989a,b) által ismertetett A kreativitás tesztek tesżtkönyve I-II. címú kiadványokban található. Ezekben a múvekben ismertetésre kerül a verbális tesztek közül: a Szokatlan használat teszt (Barkóczi, Klein, 1968) és a Távoli Asszociáció teszt (Barkóczi, Klein, 1968); a figurális tesztek közül: a Körök teszt (Torrance, 1974) és a Képbefejezés Teszt (Torrance, 1974) hazai adaptációja. E kreativitástesztek lényege: az egyéni alkotóképességet - ezen belül az ötletgazdagságot (fluenciát), a szokásostól eltérő, eredeti (originális) és rugalmas, szemléletváltásra kész (flexibilis) gondolkodást - provokáló feladathelyzetekre (ingerekre) adott megoldások (válaszok) tartalomelemzés jellegú vizsgálata.

E tesztek alkalmazása, értékelése során feltűnővé vált, hogy a kreativitást vizsgáló verbális és a nonverbális eljárásokban gyakran találkozhatunk az agresszió megjelenésének szóbeli és/vagy képi úton megfogalmazott jegyeivel is. Felmerül tehát annak lehetősége, hogy a kreativitástesztek akár az agresszióról is nyújthatnak visszajelzéseket. E lehetőség már csak azért is adott, mert ha áttekintjük az agresszió vizsgálatára alkalmazott - nem kérdőív jellegú - eljárásokat, akkor láthatjuk, hogy a kreativitástesztekhez hasonlóan azok is tartalomelemzés-szerűen közelítik meg a vizsgálati személy viselkedésében, válaszaiban jelentkező agresszív megnyilvánulásokat.

\section{Az agresszió vizsgálati lehetőségei}

A szituatív, illetve a személyiségvonás-szerūen megnyilvánuló agresszió vizsgálatára sokféle eljárást dolgoztak ki az elmúlt 60 évben. Ezeket áttekintve megfigyelhető ugyan egyfajta módszertani sokszínűség az agresszióvizsgálatok adatfelvételi és értékelési jellege tekintetében, lényegét tekintve mégiscsak két fóbb csoportba sorolhatók e vizsgálatok: a kérdőíves vizsgálatok csoportjába és a megfigyeléses/tartalomelemzéses vizsgálatok csoportjába. 
Az alábbiakban - a teljesség igénye nélkül, pusztán demonstrációs jelleggel - mutatunk be néhányat az agresszió vizsgálatára használt eljárások közül:

Az agresszivitásra való hajlam vagy azzal szoros összefüggésbe hozható személyiségvonás (önjellemző vagy másokat jellemző jellegú) kérdőíves vizsgálatára nyújt lehetőséget többek között: a Minnesota Multiphasic Personality Inventory (MMPI), illetve ennek MMPI-2 verziójában a PSY-5 skálákon belül az agresszivitást mérő AGGR-alskála (Butcher és tsai, 1989); a Reaktív/Proaktív Agresszió kérdőíve (Reactive /Proactive Agression Questionnaire, RPA - Raine és tsai, 2006); az Eysenck Personality Questionnaire (EPQ) felnôtt és gyerek változatában a pszichoticizmus (P) skála (Eysenck és Eysenck, 1975).

A mások agressziójának regisztrálására vonatkozó szempontsorok is ismertek. Ilyen például az iskolai bűnügyi prognosztikát - a bủnözésre való hajlam regisztrálását - segítő „Tanári véleményezési lista” (Münnich és Szakács, 1977; lásd még: Tóth, 2001), mely lényegét tekintve egy pedagógusok által kitölthető tanulókat jellemző szempontsor.

A vizsgálati személy tárgyakkal történó manipulációjának, illetve spontán vagy felkérésre történő (akár projektív tesztek révén provokált, vagy interjú során tapasztalt) beszédének, írásának vagy rajzolásának megfigyelése és tartalomelemzése is alkalmas az agresszivitás vizsgálatára. A tárgymanipulációs vizsgálatok közé sorolhatjuk például a „Báb játék” és a „Világ játék” révén történő vizsgálatokat (Polcz, 1988). A vizsgálati személy beszéd-produkciójának tartalomelemzése is rámutathat agressziv jegyekre: a GottschalkGleser-féle tartalomelemzési módszer (Gottschalk és Gleser, 1969). Az agresszív jelekre (is) fókuszáló tartalomelemzés tárgyai lehetnek a vizsgálati személyek által készített írott (Hárdi, 1958), illetve rajzolt alkotások (Hárdi, 2000), vagy a projektív rajzvizsgálatok (Hammer, 1997; Machover, 1980) is.
$\mathrm{Az}$ agressziót képekre adott válaszok alapján vizsgáló tesztek például: a Lüscher-próba (Mérei, 1988), a Színpiramis teszt (Herskovits, 1988) vagy a Rorschach-próba (vagy: Ro-próba; közismertebb nevén: Tintafolt teszt, Mérei, 2002). A Közös Rorschach Vizsgálat ( Bagdy, Baktay és Mirnics, 2006) szintén alkalmas a kreativitás és az agresszió megfigyelésére.

\section{Vizsgálat}

\section{A vizsgálat célja, hipotézisek}

Kutatásunk célja a kreativitástesztekben megnyilvánuló agresszió kvantitatív elemzése, az alábbi feltevések igazolása:

1. Kutatási eredmények szerint (vö.: Anderson és Bushman, 2002; Wilkowski és Robinson, 2008) léteznek az agresszivitást inkább, illetve kevésbé provokáló környezeti ingerek, ami alapján feltételezhetô, hogy a kreativitástesztek ingereire (például „tégla”, „kulcs”, „ceruza” szavakra, illetve körökre) adott agresszív válaszok mennyisége szignifikánsan különbözik.

2. Feltételezzük, hogy a kreativitástesztek egyes ingereire érkező agresszív válaszok száma között erős, pozitív irányú korrelációs kapcsolat van. Vagyis: aki az egyik ingerre sok agresszív választ ad, az a többi ingerre is relatíve sok agresszív választ ad. Feltevésünk hátterében az a gondolat áll, hogy (bár lehetnek darabszámbeli különbségek a kreativitástesztek egyes ingereire adott agresszív válaszszámok között, mégis jellemző az, hogy) az agresszivitás a kreativitás tesztekre adott válaszszámot általában véve növeli. $\mathrm{E}$ tanulmányban ezt a jelenséget kívánjuk feltárni - terjedelmi okok miatt nem célunk annak eldöntése, hogy a jelenség hátterében pszichoanalitikus megközelítésű (vesd össze.: 
Kőváry, 2012) vagy kognitív orientációjú (Berkowitz, 1990) magyarázat állhat-e.

3. Valószínűsíthető, hogy a kreativitástesztekre adott agresszív válaszok számában különbségeket fogunk találni nemenként és korcsoportonként is. Feltételezzük, hogy a férfiak, illetve a fiatalabb korosztályba tartozók fognak több agresszív választ adni - egyrészt a nemi sztereotípiák (ti., a férfiak szókimondóbbak, agresszívebbek) és vizsgálati eredmények (vö.: Nguyen Luu, 2002), másrészt a „fiatalabbakra kevésbé jellemző az önkontroll” jellegú sztereotípiák miatt. További kutatásunk szempontjából ennek el döntése a jövőbeli differenciált mintavétel és az agresszivitásmutatók standardképzése szempontjából lényeges.

\section{Vizsgálati minta}

A vizsgálatban összesen 356 személy vett részt. Nemi és korcsoportbeli összetételüket az 1. táblázat foglalja össze. A vizsgálati minta kiválasztásának indoklása: a kreativitásteszteket leginkább a pályaorientációs gyakorlatban használják. Ez az iskolaválasztás előtt álló 13-14 éves (továbbiakban: általános iskolás) korcsoportot, illetve a 17-18 év körüli (továbbiakban: középiskolás) korcsoportot érinti közvetlenül. A felnőtt korcsoportba tartozók (20-65 évesek) almintáját azok alkották, akik egy hátrányos helyzetú társadalmi csoportok felzárkóztatását célzó program keretében zajló képzés tartósan munkanélküli résztvevői voltak.

A vizsgálati minta reprezentativitása: noha ez a minta nem tekinthetô reprezentatívnak, jelen tanulmány céljára (egy hosszú távú validálási és skálafejlesztési munka első állomásaként történő elemzésére) alkalmasnak tekinthetô. A reprezentativitás legjobban a felnôtt alminta esetében sérül, hiszen vélhetóen jobban reprezentálja ez az alminta a tartósan munkanélküli felnőtteket, mint általában a felnőtteket. Ezért, a felnőtt vizsgálati személyekre történő hivatkozásnál minden esetben jelöljük, hogy tartósan munkanélküli felnőttekről van szó.

Jelen vizsgálatunkba történő figyelembevételüket azért tartottuk mégis indokoltnak, mert a munkanélküliség gyakran frusztrációval jár (Benedek, 1996), s Dollard és tsai (1939) frusztráció-agresszió hipotézise alapján e csoport esetében is számíthatunk agresszív válaszokra (ami validációs jelentőséggel bírhat a kreativitástesztek agresszió-vizsgálatra történő alkalmazása szempontjából).

1. táblázat. A vizsgálati minta korcsoportbeli és nemi összetétele. Forrás: Szerző́k.

\begin{tabular}{|l|l|l|}
\hline Nemek & Korcsoportok & $\mathrm{N}$ (fö) \\
\hline \multirow{4}{*}{ Férfiak: } & Általános iskolás korcsoport (13-14 év): & 25 \\
\cline { 2 - 3 } & Középiskolás korcsoport (17-18 év): & 25 \\
\cline { 2 - 3 } & Felnőttek (20-65 éves, tartósan munkanélküliek): & 60 \\
\cline { 2 - 3 } & Férfiak összesen: & 110 \\
\hline \multirow{4}{*}{ Nők: } & Általános iskolás korcsoport (13-14 év): & 50 \\
\cline { 2 - 3 } & Középiskolás korcsoport (17-18 év): & 126 \\
\cline { 2 - 3 } & Felnőttek (20-65 éves, tartósan munkanélküliek): & 70 \\
\cline { 2 - 3 } & Nók összesen: & 246 \\
\hline & Általános iskolás korcsoport (13-14 év): & 75 \\
\cline { 2 - 3 } & Középiskolás korcsoport (17-18 év): & 151 \\
\cline { 2 - 3 } & Felnôttek (20-65 éves, tartósan munkanélküliek): & 130 \\
\cline { 2 - 3 } & Mindösszesen: & 356 \\
\hline
\end{tabular}




\section{Módszer}

Jelen vizsgálatban a Szokatlan használat (verbális) és a Körök (nem verbális) kreaivitástesztet vettük fel vizsgálati személyeinkkel. A Szokatlan használat teszt során három ingerszót („tégla”, „kulcs”, „ceruza”) alkalmaztunk, a Körök teszt esetében ingerként 5 oszlopba és 7 sorba rendezett 35 darab egyforma méretű kör szolgált. A tesztek részletes bemutatása megtalálható: Zétényi, 1989a,b.

Tanulmányunkban e tesztek fluencia (ötletgazdagság) változójának agresszió szempontú elemzésére fókuszálunk. A fluencia Zétényi (1989a,b) alapján történő értékelésén túl, a vizsgálati személyek válaszait egyfajta tartalomelemzésnek vetettük alá az agresszió szempontjából. A Rorschach-próba agresszió vizsgálatát (Mérei, 2002) alapul véve agresszívnek tekintettük azokat a válaszokat, amelyek agresszióval kapcsolatba hozható cselekvésekre (például: ölni, gyilkolni, fejbe verni valakit, emberáldozat stb.), tárgyakra (pl. kés, fegyver stb.), szimbólumokra (például: az anarchia jele), érzelmekre (például: „agresszív fej”, gonosz stb.), lényekre (például: vámpír, szörny) utalnak.

A statisztikai számításokat az SPSS for Windows 13.0 szoftverrel végeztük.

\section{Eredmények}

Különbségek a kreativitástesz̨tek, ingereire érkęő" agressziv válaszok száma között

A két kreativitásteszt négy ingerére összesen 9893 választ adott a 356 vizsgálati személy - de a válaszok száma igen eltérő volt. Az eredmények későbbi értelmezése céljából az értékelést e válaszszámbeli különbségek bemutatásával kezdjük. Az összes válasz száma a „tégla” esetében 1437, a „kulcs” esetében 1162, a ceruza esetében 1310, s a körök vonatkozásában 5984 darab volt. A Wilcoxon-féle elójeles rangösszeg próba eredményei szerint: az ingerpárokra adott válaszok száma közötti különbségek szignifikánsak (2. táblázat).

Noha a Szokatlan használat teszt három ingerszava esetében tapasztalható különbség is figyelemre méltó, itt és most a két teszt közötti nagyfokú eltérésre szeretnénk felhívni a figyelmet. A Körök tesztre érkezett 5984 válasz 2075 darab válasszal több, mint a Szokatlan használat teszt három („tégla”, „kulcs”, „ceruza”) ingerszavára összesen érkezett 3909 válasz!

Ennek oka lehet:

a) a „körök” non-verbális feladatjellege (szemben a szokatlan használat ingerszavainak verbális feladataival). E feltételezést a jövőben más verbális/nonverbális ingerek bevonásával (pl. körök helyett négyzetek, amorf alakzatok, a szokatlan használat tesztben pedig más tárgyak megjelölésével) tesztelhetjük;

b) a Körök-teszt esetében eleve 35 kört tartalmaz a vizsgálati lap, ami arra motiválhatja a vizsgálati személyeket, hogy ha még maradt „üres” kör, akkor tovább kell próbálkoz-niuk. A szokatlan használat teszt hívószavai esetében azonban nincs ilyen direkt, teljesítményre ösztönző vizuális tényező (pl. 35 gondolatjel).

2. táblázat. Ingerpárok különbsége az összes válasz tekintetében. Forrás: Szerzők.

\begin{tabular}{lllllll} 
& Kulcs - Tégla & Ceruza - Tégla & Körök - Tégla & Ceruza - Kulcs & Körök- Kulcs & Körök - Ceruza \\
\hline Z & $-6,922$ & $-3,686$ & $-17,934$ & $-3,507$ & $-18,203$ & $-18,120$ \\
\hline p & 0,000 & 0,000 & 0,000 & 0,000 & 0,000 & 0,000 \\
\hline
\end{tabular}


Eredményeink szerint az egyes ingerek nemcsak eltérő mértékben provokálnak válaszszámot, de különböznek abban a tekintetben is, hogy mennyi agresszívnak tekinthetô választ adnak rájuk. Páronkénti összehasonlítás elvégzésekor hipotézisünk (a „Ceruza”-,,Tégla” ingerpár kivételével) valamennyi ingerpár esetében igazolódott. Részletesen: a 356 vizsgálati személyből 174 fó (a minta 48,88\%-a!) összesen 357 agresszív választ adott (ez a tesztekre összesen érkezett 9893 válasz 3,61\%-a). Tehát miközben aggasztó lehet az agresszív választ adó személyek magas aránya, az agresszív válaszok mennyisége az összes válaszhoz képest viszonylag csekély. Ennek gyakorlati jelentőségére a tanulmány végén térünk ki.

A legkevesebb agresszív válasz (összesen: 19; a teljes mintát figyelembe véve az átlag $=0,05$ és a szórás $=0,344 ;$ az agresszív válaszokat adók szúkebb almintája esetében az átlag $=0,11$ és a szórás $=0,486)$ a Körök-tesztre érkezett. Tehát arra az ingerre, amelyre (mint fentebb láthattuk) a legtöbb választ kaptuk!) Valamivel több az agresszív válaszok átlagos száma a szokatlan használat teszt „kulcs” ingerszava esetében (a teljes minta esetében az átlag $=0,16$ és a szórás $=0,435$; az agresszív alminta esetében pedig az átlag $=0,32$ és a szórás $=0,579)$. A legtöbb agresszív választ a Szokatlan használat teszt „tégla”, illetve „ceruza” ingerszava provokálta (a teljes minta átlagai ezek esetében 0,41 és 0,38; a szórások: 0,684 és 0,658). Az agresszív alminta átlagai: 0,84 és 0,78 agresszív válasz; s a szórás ezek esetében is a legnagyobb: 0,771; illetve 0,761). A Wilcoxon-féle előjeles rangösszeg próba eredménye szerint (3. táblázat): a „ceruza” és a „tégla” inger-pár kivételével (mely ingerek egymáshoz hasonlóan, s a másik két ingernél erőteljesebben provokáltak agressziv válaszokat) valóban szignifikánsan különböznek egymástól az ingerek az agresszív választ provokáló jellegükben.

Ennek hátterében egyrészt azt sejtjük, hogy az ingerként megadott tárgyak („tégla”, „kulcs”, „ceruza") szorosabb asszociációt engednek meg agresszív tudattartalmakkal, mint a „körökhöz” hasonló, kevésbé tárgyszerú szimbolikus ingerek. Másrészt a tárgyakkal kapcsolatos korábbi közvetlen vagy közvetett (például filmélményeken alapuló) tapasztalatok, valamint a tárgyak fizikai jellegzetességeivel kapcsolatban felmerülő asszociációk (súly, szúrásra alkalmas hegy, fegyverhez való hasonlóság - vö.: Anderson és Bushman, 2002) is hatással lehetnek az agresszív válaszok megjelenésében.

A kreativitástesztek ingereinek ,agresszióra való felhívó jellege" közötti különbség gyakorlati következménye, s további kutatási lehetőségek például: úgy túnik, hogy a kreativitástesztekre adott válaszokban valóban tetten érhetôk agresszív megnyilvánulások. Ez felveti annak a lehetôségét, hogy e tesztek az agresszív megnyilvánulások vizsgálatára is alkalmasak lehetnek, vagy alkalmassá tehetôk.

Ennek gyakorlati haszna például az lenne, hogy egységnyi adatfelvételi (idő-, pénz-, energia-) befektetés révén a kreativitásra vonatkozó adatokon túlmutató többlet információhoz juthatunk. Az ilyen jellegú teszt felhasználás szükségessé teszi azonban, hogy a jövőben a kreativitástesztekre adott agresszív válaszok számát validáljuk azokkal az eredményekkel, amelyeket az agresszió megfigyelése, a múltbeli/jelenlegi agresszív megnyilvánulások regisztrálása, illetve az agresszióra vonatkozó kérdôíves és projektív személyiségvizsgálatok elvégzése során nyerünk.

3. táblázat. Ingerpárok különbsége az agressziv válaszok tekintetében. Forrás: Sz̨rzôk.

\begin{tabular}{lllllll} 
& Kulcs - Tégla & Ceruza - Tégla & Körök - Tégla & Ceruza - Kulcs & Körök - Kulcs & Körök - Ceruza \\
\hline Z & $-7,354$ & $-0,802$ & $-9,006$ & $-5,939$ & $-4,166$ & $-9,249$ \\
\hline p & 0,000 & 0,423 & 0,000 & 0,000 & 0,000 & 0,000 \\
\hline
\end{tabular}




\section{Korrelációk a kereativitástesztete ingereire érkęóó} agressziv válaszok száma között

A kreativitás tesztek ingereire érkezett összes válasz-számok közötti korrelációkat tekintve figyelemre méltó, hogy amíg a Szokatlan használat teszt verbális ingerei között szignifikáns, viszonylag erős $(\mathrm{r}=0,653$ és 0,711 közötti; mindegyik esetben $\mathrm{p}<0,001)$ pozitív irányú együttjárás tapasztalható, a Szokatlan használat teszt és a Körök teszt ingerei közötti korrelációs kapcsolat legjobb esetben is gyengének tekinthető ( $\mathrm{r}=0,277$ és 0,333$)$.

$\mathrm{Az}$ ingerekre érkező agresszív válaszok száma közötti kapcsolatok esetében szignifikáns $(\mathrm{p}<, 001)$ pozitív korrelációt három (a Szokatlan használat teszthez kötődő) ingerpár esetében találtunk. Ezek: „tégla-kulcs” ( $\mathrm{r}=0,396)$; „tégla-ceruza” ( $\mathrm{r}=0,414)$; „kulcs-ceruza” ( $(\mathrm{r}=0,234)$. A Körök tesztre érkezett agresszív válaszok száma és a Szokatlan használat teszt ingereire érkezett válaszok száma között még ilyen mértékú szignifikáns együttjárást sem tapasztaltunk. E jelenség (egymást nem kizáró) lehetséges okai: a) a kreativitástesztek ingerei (mint fentebb szó volt róla) eltérô mértékben provokálnak agresszív válaszokat; b) a kreativitástesztek exponálásának sorrendje; c) a kreativitás teszt verbá- lis/nonverbális jellege és a vizsgálati személyek preferált (agresszió) kifejezési módja (tekintve, hogy verbálisan vagy nem verbálisan fejezik-e ki inkább agressziójukat). Például: feltehetően többször ejtünk ki agresszív megnyilvánulásokat a szánkon, mint ahányszor lerajzoljuk azokat.

\section{Mintaváltozók közötti különbségek}

A Kruskal-Wallis próba eredménye szerint szignifikáns különbség van a különböző nemű és korcsoportba tartozó személyek válaszainak és agresszív válaszainak mennyisége tekintetében (4. táblázat) - bár a csoportok közötti különbség minden esetben kisebb, mint egy teljes válasz. A nemek tekintetében a nôk, a korcsoportok tekintetében az iskolás korúak adtak kevesebb agresszív választ. Az utótesztként (a „Nem” és a „Korcsoport” változók értékeinek kombinálásával létrehozott) csoportonkénti páros összehasonlítással végzett MannWhitney-féle U-próba eredménye szerint a középiskolás lányok különböztek leginkább a többi csoporttól - vagyis: a vizsgálati mintában legnagyobb számmal jellemezhető „Nem x Korcsoport” alminta agresszív válasz-száma kevesebb, mint a többi almintáé.

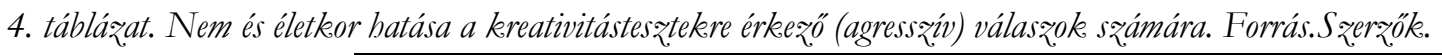

\begin{tabular}{|c|c|c|c|c|c|c|c|c|c|}
\hline & & \multirow{2}{*}{\multicolumn{4}{|c|}{ Összes válasz }} & \multirow{2}{*}{\multicolumn{4}{|c|}{ Agresszív válaszok }} \\
\hline & & & & & & & & & \\
\hline & & \multicolumn{3}{|c|}{ Szokatlan használat teszt } & \multirow{2}{*}{$\begin{array}{l}\text { Körök } \\
\text { teszt }\end{array}$} & \multicolumn{3}{|c|}{ Szokatlan használat teszt } & \multirow{2}{*}{$\begin{array}{l}\text { Körök } \\
\text { teszt }\end{array}$} \\
\hline & & Tégla & Kulcs & Ceruza & & Tégla & Kulcs & Ceruza & \\
\hline \multirow{3}{*}{ 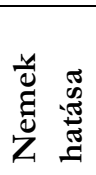 } & Khi-négyzet & 0,024 & 0,771 & 4,972 & 0,006 & 5,141 & 11,067 & 6,085 & 3,336 \\
\hline & Szabadságfok & 1 & 1 & 1 & 1 & 1 & 1 & 1 & 1 \\
\hline & Szignifikancia & 0,878 & 0,380 & $0,026^{*}$ & 0,941 & $0,023^{*}$ & $0,001 * *$ & $0,014^{*}$ & 0,068 \\
\hline \multirow{3}{*}{ 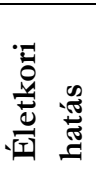 } & Khi-négyzet & 21,120 & 24,725 & 21,089 & 21,708 & 9,044 & 20,373 & 9,973 & 1,341 \\
\hline & Szabadságfok & 2 & 2 & 2 & 2 & 2 & 2 & 2 & 2 \\
\hline & Szignifikancia & $0,000^{* *}$ & $0,000 * *$ & $0,000 * *$ & $0,000 * *$ & $0,011^{*}$ & $0,000^{* *}$ & $0,007 * *$ & 0,511 \\
\hline \multirow{3}{*}{ 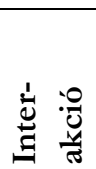 } & Khi-négyzet & 27,659 & 28,843 & 26,065 & 27,589 & 17,508 & 32,660 & 21,081 & 19,159 \\
\hline & Szabadságfok & 5 & 5 & 5 & 5 & 5 & 5 & 5 & 5 \\
\hline & Szignifikancia & $0,000 * *$ & $0,000^{* *}$ & $0,000 * *$ & $0,000 * *$ & $0,004 * *$ & $0,000 * *$ & $0,001 * *$ & $0,002 * *$ \\
\hline
\end{tabular}


Hogy ennek hátterében ténylegesen az áll-e, hogy a középiskolás lányok kevésbé agresszívek, vagy arról van szó mindössze, hogy kevésbé jellemzô rájuk az agresszió ilyen jellegú kifejezése, azt további vizsgálatok dönthetik majd el. Mindent összevetve: amikor egy vizsgálati személy kreativitástesztekben megnyilvánuló agresszív válaszainak mennyiségét elemezzük a nemi és korcsoportbeli differenciálásnak van alapja.

\section{Megvitatás}

Tanulmányunkban a kreativitás és az agresszió kapcsolatát magyarázó pszichológiai megközelítések, illetve e két tényező vizsgálati lehetôségeinek leltárba vétele után egy vizsgálatot mutattunk be $(\mathrm{N}=356)$, melynek célja a kreativitástesztekre érkező agresszív válaszok elemzése volt.

Eredményeink alapján számszerűsíteni tudtuk a kreativitástesztekben megnyilvánuló agresszív válaszokat. E számok ismeretében elmondható, hogy a kreativitástesztekre adott válaszokban megnyilvánuló agresszivitás figyelemfelhívó voltának megítélése függ attól, hogy az agresszív választ adó személyek arányát $(48,88 \%)$ vagy az agresszív válaszok arányát (3,61\%) tekintjük-e. Az, hogy a vizsgálati személyek igen nagy hányada (mintegy fele) adott agresszív válaszokat, már önmagában is felhívja a figyelmet a csoportos mértékben jelentkező agresszióra. Ehhez képest az önmagában viszonylag alacsony agresszív válaszarányt (tévesen) úgy is értelmezhetnénk, hogy e tesztek nem érzékenyek az agresszióra, tehát nem alkalmasak az emberek megbízható megkülönböztetésére az agresszió szempontjából. Ugyanakkor az egyéni értékelés aspektusából lényeges gyakorlati következmény, hogy relatív gyakoriságuk csekély mértéke miatt a kreativitástesztekben megnyilvánuló agresszív válaszoknak „vészjelző” funkciójuk lehet akkor, amikor egy-egy adott személy eredményeit értékeljük. Ha az egyén válaszaiban (különösen: az összes válaszához viszonyítva nagy arányban!) megjelennek agresszív megnyilvánulások (holott az másokra olyan mértékben nem jellemző, tehát nem általános jelenség), akkor ez a pszichológiai jellegú konzultáció, tanácsadás során figyelemreméltó információnak tekinthető!

Jelen vizsgálat folytatásaként a jövőben egyrészt a kreativitástesztekben fellelhető agresszivitás kérdőíves és megfigyeléses jellegú validációs vizsgálataira kell figyelmet fordítani; másrészt a kreativitástesztekből számítható egyfajta agresszivitás-index konstruálására tehetünk kísérletet; harmadrészt további (a kreativitásvizsgálatok tartalomelemzése során megnyilvánuló) nonkognitív változók azonosítására koncentrálhatunk.

\section{Irodalom}

Adler, A. (1994): Életünk jelentése. Kossuth Kiadó, Budapest.

Anderson, C. A., Bushman, B. J. (2002). Human aggression. Annual Review of Psychology, 53, 27-51. doi 10.1146/annurev.psych.53.100901.135231

Bagdy,E., Baktay Z.,Mirnics Zs. (2006): Pár és családi kapcsolatok vizsgálata. HEFOP Digitális tankönyv, Budapest.

Barkóczi, I., Klein, S. (1968): Gondolatok az alkotóképességről és vizsgálatának problémáiról. Pszichológiai Szemle, 25. s\%, 508-515.

Benedek, L. (1996): Tanácsadás munkanélküilieknek. Kézikönyv a szociális munka gyakorlatához. OMK., Budapest.

Berkowitz, L. (1990). On the formation and regulation of anger and aggression: A cognitiveneoassociationistic analysis. American Psychologist, 45, 494-503. doi 10.1037 // 0003-066x.45.4.494

Butcher, J. N., Dahlstrom, W. G., Graham, J. R., Tellegen, A., Kaemmer, B. (1989): The Minnesota Multiphasic Personality Inventory-2 (MMPI-2): Manual for administration and scoring. Minneapolis, $\mathrm{MN}$ : University of Minnesota Press.

Cropley, d. H., Cropley, A. J. , Kaufman, J. C., Runco, M. A. (eds.)(2010): The dark side of creativity. Cambridge University Press, Cambridge. 
Cropley, D.H., Kaufman, J.C., \& Cropley, A.J. (2008). Malevolent creativity: A functional model of creativity in terrorism and crime. Creativity Research Journal, 20, 105-115. doi $\underline{10.1080 / 10400410802059424}$

Cropley, D.H., Kaufman, J.C., White, A.E., \& Chiera, B.A. (2014). Layperson perceptions of malevolent creativity: The good, the bad, and the ambiguous. Psychology of Aesthetics, Creativity, and the Arts, 8, 400-412. doi 10.1037/a0037792

Dacey, J. S., Lennon, K.H. (1998): Understanding creativity. San Francisco, CA: Jossey-Bass.

Davis, G. A., Rimm, S. B. (1982): Group Inventory For Finding Interests (GIFFI I and GIFFI II): Instruments for Identifying Creative Potential in Junior and Senior High Schools. Journal of Creative Behavior, 16(1), 50-57. doi 10.1002/j.21626057.1982.tb00321.x

Dollard, J., Doob, L.W., Miller, N.E., Mowrer, O.H., Sears, R.R.(1939): Frustration and aggression, New Haven: Yale University Press

Dumas, D.G., \& Strickland, A.L. (2018). From book to bludgeon: A closer look at unsolicited malevolent responses on the alternate uses task. Creativity Research Journal, 30, 439-450. doi $\underline{10.1080 / 10400419.2018 .15357}$

Erikson, E. H. (2002 [1950]): Gyermekkor és társadalom. Osiris, Budapest.

Eysenck, H. J., Eysenck, S. B. G. (1975): Manual of the Eysenck Personality Questionnaire. London: Hodder and Stoughton.

Feist, G. J. (1999): The influence of personality on artistic and scientific creativity. In Sternberg, R. J. (ed.): Handbook of creativity. New York, NY: Cambridge University Press. 273-296.

Freud, S. (1986 [1917]): Bevezetés a pszichoanalizisbe. Gondolat Könyvkiadó, Budapest.

Fromm, E. (1959): The creative attitude. In Anderson, H. (ed.): Creativity and its cultivation. Harper \& Row, New York, 44-55.

Gottschalk, L. A., Gleser, G. C. (1969): The measurement of psychological states through the content analysis of verbal behavior. Berkeley: Univ. of California Press.

Guilford, J.P. (1959): Traits of creativity. In Anderson, H. (ed.): Creativity and its cultivation. Harper \& Row, New York. 142-162.

Gyarmathy, É. (2011): Kreativitás és beilleszkedési zavarok. In Münnich, Á. (ed.): A kreativitás többszempontú vizsgálata. Didakt Kiadó, Debrecen. 940.

Hammer, E. F. (1997): Advances in Projective Drawing Interpretation. Thomas, Springfield.

Hárdi, I. (1958): Íráspszichológiai megfigyelések elektroshock-kezelés nyomán. In Pszichológiai Tanulmányok I. Akadémiai Kiadó, Budapest. 303309.

Hartmann, H. (1955): Notes on the theory of sublimation. Psychoanalytic Study of the Child, 1955, 10, 9-29.

Herskovits, M. (1988): A szinpiramis teszt. In: Mérei, F., Szakács, F.(eds.): Pszichodiagnosz̧tikai vademecum II. Személyiségtesztek 3. rész. Tankönyvkiadó, Budapest. 186-269.

James, K., Clark, K., and Cropanzano, R. (1999). Positive and negative creativity in groups, institutions, and organizations: a model and theoretical extension. Creat. Res. J. 12, 211-226. doi $10.1207 / \mathrm{s} 15326934 \mathrm{crj} 1203$ _ 6

Johnson, D. L. (1979): The Creativity Checklist. Wood Dale: Stoelting.

Jonason, P.K., Abboud, R., Tomé, J., Dummett, M., \& Hazer, A. (2017). The Dark Triad traits and individual differences in self-reported and otherrated creativity. Personality and Individual Differences, 117, 150-154. doi 10.1016/i.paid.2017.06.005

Kirschenbaum, R. J. (1989): Understanding the Creative Activity of Students. Mansfield: Creative Learning Press.

Klein, M. (1999): A sqó elótti tartomány. Akadémiai Könyvkiadó, Budapest.

Koestler, A. (1998): A teremtés. Európa Könyvkiadó, Budapest. 
Kőváry, Z. (2012): Kreativitás és személyiség. Oriold és társai, budapest.

Kumar, V. K., Kemmler, D., Holman, E. R. (1997): The Creativity Styles Questionnaire revised, Creativity Research Journal, 10, 51-58. doi 10.1207/s15326934crj1001_6

Landau, E. (1994): Az agresszió, mint kreatív energia. In Balogh L., Herskovits M., Tóth L. (szerk.): A tehetségejlesztés pszichológiája. Kossuth Egyetemi Kiadó. Debrecen. 83-92.

Machover, K. (1980): Personality Projection in the Drawing of the Human Figure. Thomas, Springfield.

Maslow, A. (2003): Az önmegvalósító ember kreativitása. In Maslow, A. (szerk.): A lét pszicbológiája felé. Ursus Libri Kiadó, Bdapest, 219-235.

May, R. (1959): The nature of creativity. In Anderson, H. (ed.): Creativity and its cultivation. Harper \& Row, New York. 55-69.

Mednick, S.A. (1962): The associative basis of creativity. Psychological Review, 69, 220-232. doi $10.1037 / \mathrm{h} 0048850$

Mentzos, S. (2003): A konkfliktus-feldolgozás neurotikus útjai. Lélekben Otthon, Budapest.

Mérei, F. (1988): A Lüscher próba klinikai alkalmaz̃ása. In Mérei, F., Szakács, F. (eds.): Pszichodiagnosztikai vademecum II. Személyiségtesztek 3. rész. Tankönyvkiadó, Budapest. 163-185.

Mérei, F. (2002): Rorschach-próba. Medicina Könyvkiadó Rt., Budapest.

Münnich, I., Szakács, F. (eds.) (1977): Bünözó" fiatalok. Közgazdasági és Jogi Könyvkiadó, Budapest.

Nguyen Luu, L. A. (2002): A nemek szerepe az iskolában. In Mészáros A. (eds.): $A$ z iskola szociálpszichológiai jelenségvilága. ELTE Eötvös Kiadó, Budapest. 118-143.

Perchtold, C.M., Papousek, I., Koschutnig, K., Rominger, C., Weber, H., Weiss, E.M., \& Fink, A. (2018). Affective creativity meets classic creativity in the scanner. Human Brain Mapping, 39, 393-406. doi 10.1002/hbm.23851
Polcz, A. (1988): A „Báb-játék” és „Világ játék”: aktív játékdiagnosztika és terápia. In Mérei, F., Szakács, F. (eds.): Pszichodiagnosz̨tikai Vade-mecum. II. Személyiségtesattek. 1. rész. Tan-könyvkiadó, Budapest. 25-124.

Raine, A., Dodge, K., Loeber, R., Gatzke-Kopp, L., Lynam, D., Reynolds, C., Stouthamer-Loeber, M., Liu, J. (2006): The reactive-proactive aggression questionnaire: differential correlates of reactive and proactive aggression in adolescent boys. Aggressive Behavior, Vol. 32, issue 2, 159-171. doi $\underline{10.1002 / \mathrm{ab} .20115}$

Rogers, C. (2004): Egy kreativitáselmélet vázlata. In Rogers, C. (szerk.): Valakivé válni. A személyiség születése. Edge 2000 Kiadó, Budapest, 433-446.

Runco, M., Sakamoto, S. O. (1999): Experimental studies of creativity. In Sternberg, R. J. (ed.): Handbook of creativity. New York, NY: Cambridge University Press. 62-92.

Runco, M.A. (2010). Creativity has no dark side. In Cropley, A.J., Kaufman, J.C. \& Runco, M.A. (Eds.), The dark side of creativity(pp. 15-32). New York, NY: Cambridge University Press.

Sullivan, H. S. (1996): Posztulátumok. In Szakács, F., Kulcsár, Zs. (szerk.): Személyiséglélektani szöveggyüjtemény II., Nemzeti Tankönyvkiadó, Budapest. 140-159.

Süle, F. (1988): A „Fa-rajz”-teszt. In Mérei, F., Szakács, F.(eds.): Pszichodiagnosz̨tikai Vademecum. II. Személyiségtesæteke 2. résæ: Tankönyvkiadó, Budapest. 89-148.

Szőnyi, M. (1988): Jacqueline Royer Metamorfózisok tesztjének diagnosztikus alkalmazása, valamint 300 budapesti gimnazista jegyzőkönyvének feldolgozása. In Mérei, F., Szakács, F. (eds.): Pszichodiagnosztikai vademecum II. Személyiségtesżtek 3. rész. Tankönyvkiadó, Budapest. 99-159.

Tacher, E. L., Readdick, C. A. (2006): The relation between aggression and creativity among second graders. Creativity Research Journal, 18, 261-267. doi $\underline{10.1207 / \mathrm{s} 15326934 \mathrm{crj} 1803 \quad 3}$ 
Torrance, E. P. (1974): The Torrance Tests of Creative Thinking-Norms-Technical Manual Research Edition$V$ erbal Tests, Forms $A$ and B-Figural Tests, Forms $A$ and $B$. Princeton, NJ: Personnel Press.

Tóth, L. (2001): Tanári véleményezési lista. In Tóth, L. (ed.): Pszichológiai módszerek a tanulók megismerésébez. (szöveggyüjtemény). Debreceni Egyetemi Kiadó, Debrecen. 55-61.

Tóth, L.(2011): A Tóth-féle Kreativitás Becslő Skála (TKBS). In Münnich Ákos (ed.), A kreativitás többszempontú vizsgálata (65-88) Didakt Kiadó, Debrecen.

Tóth, L., Király, Z. (2006): Új módszer a kreativitás megállapítására: a Tóth-féle Kreativitás Becslő
Skála (TKBS). Magyar Pedagógia, 106 (4), 287-311. Wilkowski, B. M., Robinson, M. D. (2008). The Cognitive Basis on Trait Anger and Reactive Aggression: An Integrative Analysis. Personality and Social Psychology Review, 12, 3-21. doi $\underline{10.1177 / 1088868307309874}$

Winnicott, D. (1999): A kreativitás eredete. In Winnicott, D. (szerk.): Játsæás és valóság. Animula, Budapest. 65-85.

Zétényi, T. (1989b): A kreativitás tesz̨tek tesz̧tkönyve II., Munkaügyi Kutató Intézet, Budapest.

Zétényi, T.(1989a): A kreativitás tesz̨tek tesztkönyve I., Munkaügyi Kutató Intézet, Budapest. 